\title{
Megeguritan: Media Pendidikan Karakter Generasi Muda Dalam Menghadapi Arus Budaya Global (Studi Kasus Di Desa Pakraman Bresela Payangan Gianyar)
}

\author{
Ida Bagus Brata ${ }^{1}$, I Komang Sudirga ${ }^{2}$
}

${ }^{1}$ Program Studi Pendidikan Sejarah FKIP Unmas Denpasar

${ }^{2}$ Fakultas Seni Pertunjukan, Institut Seni Indonesia Denpasar

ibbrata@gmail.com

Dewasa ini timbul kekhawatiran di kalangan masyarakat terhadap kelakuan generasi muda akibat pengaruh globalisasi, sehingga dituntut terciptanya sumber daya manusia berkualitas, berkarakter, imtak (iman dan takwa) untuk terwujudnya insan cerdas berakhlak mulia tidak tercerabut dari akar budaya bangsanya. Tulisan ini bertujuan mengkaji Megeguritan sebagai Media Pendidikan Karakter bagi Generasi Muda dalam menghadapi Arus Budaya Global. Metode yang digunakan dalam kajian ini adalah induktif kualitatif dengan pendekatan eksploratif dalam latar yang alamiah. Hasil kajian menunjukkan: Megeguritan merupakan karya sastra tradisional dan klasik masyarakat Bali. Geguritan merupakan sebuah wujud kebudayaan, yaitu kebudayaan yang berbentuk karya sastra Bali. Di dalam karya sastra ini banyak mengandung nilai-nilai pendidikan karakter yang sangat baik bagi perkembangan manusia, khususnya bagi generasi muda, terutama di dalam menghadapi dinamika masyarakat dalam peradaban global. Pada kenyataannya tidak ada masyarakat yang dapat bersembunyi atau menghindar dari tekanan arus budaya global. Kuatnya arus budaya global tidak terlepas dengan semakin canggihnya perkembangan teknologi, telekomunikasi, dan transportasi. Untuk mengantisipasi pengaruh negatif akibat globalisasi, maka setiap bangsa harus berusaha memprotek dirinya agar jangan tergerus oleh budaya global tersebut. Generasi muda merupakan aset bangsa, wajib dijaga agar tetap memiliki jati diri yang kokoh jangan sampai terseret arus negatif budaya global.

Kata kunci: megeguritan, globalisasi, pendidikan karakter

\section{Megeguritan: Young Generation Character Education Media In Facing Global Cultural Flows (A Case Study In Traditional Bresela Villave, Payangan District Gianyar Regency)}

Nowadays, there is concern among the public about the behavior of young generation due to the influence of globalization. Consequently, it requires the creation of quality human resources, character, faith and piety to realize noble, and intelligent people who are not deprived of their nation's cultural roots. This paper aims to examine megeguritan as character education media for young generation in facing the flow of global culture. Qualitative inductive with an explorative approach in a natural setting was used in this study. The results showed that megeguritan is a traditional and classical literary work of Balinese people. It is a form of culture; culture in the form of Balinese literature. Many values of character education are very good for human development, especially for the young generation, especially in dealing with the dynamics of society in global civilization. In reality, no community can hide or avoid the pressure of currents global culture. The strong flow is inseparable from the increasingly sophisticated developments in technology, telecommunications, and transportation. To anticipate the negative effects, every nation must try to protect itself so that it is not eroded by the global culture. The young generation is a nation's asset. They must be maintained so that they have strong identity in order to protect negative flow of global culture.

Keywords: megeguritan, globalization, character education

Proses Review : 1 - 18 April 2019, Dinyatakan Lolos: 22 April 2019 


\section{PENDAHULUAN}

Akhir-akhir ini ada anggapan sebagian masyarakat bahwa kelakuan kaum remaja begitu memperihatinkan. Untuk menghadapinya, dituntut membangun ketangguhan nasional di segala bidang. Salah satu tuntutannya adalah bagaimana upaya menciptakan sumber daya manusia yang berkualitas, berkarakter, iman, dan taqwa sehingga tercipta sumber daya manusia cerdas berakhlak mulia dan tidak tercerabut dari nilai-nilai budaya bangsanya.

Pendidikan karakter dalam sistem pendidikan di Indonesia bukanlah sesuatu yang baru. Pendidikan karakter yang dibangun melalui sistem pendidikan di Indonesia telah menjadi bagian strategis dalam misi pendidikan nasional bangsa Indonesia. Akhir-akhir ini pendidikan karakter kembali menjadi wacana yang berkembang luas di masyarakat sebagai respons atas berbagai persoalan bangsa terutama yang berkaitan dengan masalah dekadensi moral seperti berbagai tindak kekerasan, premanisme, begal, korupsi, perkelahian dan kekerasan pelajar, konflik etnis, perilaku seks bebas, perilaku lesbi, ketidakjujuran, perilaku merusak diri sendiri, mabuk-mabukan, konvoi atau trek-trekan dijalanan, genk motor, penggunaan narkoba yang cenderung semakin meningkat.

Dari sekian banyak persoalan moral, yang tampaknya lebih memperihatinkan adalah meningkatnya tindak kekerasan di kalangan remaja. Tindak kekerasan yang terjadi mulai dari jenjang pendidikan dasar, menengah sampai pendidikan tinggi. Bukan hanya siswa dan mahasiswa saja sebagai pelakunya, namun justru dilakukan oleh guru atau pendidik yang ikut menodai citra dunia pendidikan dengan melakukan tindak kekerasan seperti penculikan sampai pelecehan terhadap peserta didiknya.

Perilaku anak-anak remaja yang demikian dapat dijumpai baik di sekolah, di keluarga maupun di masyarakat. Permasalahan yang paling menonjol di kalangan anak-anak remaja yang ada di lokasi penelitian, seperti perilaku tidak jujur terhadap orang tua, sulit dinasehati bahkan sering membantah nasehat orang tua, suka minum-minuman, terlalu asyik bermedsos ria sehingga cenderung mengabaikan tugas yang diberikan orang tua, dan suka kebut-kebutan di jalan sehingga mengancam keselamatan orang lain bahkan dirinya sendiri.

Perilaku anak-anak remaja yang demikian patut diduga akibat kurang meresapi ajaran agama untuk dipraktekkan dalam kehidupan sehari-hari. Ajaran agama sesungguhnya tidak semata-mata dapat ditemukan pada buku-buku teks agama, namun ajaran tentang kesusilaan sebagai bagian penting ajaran keagamaan banyak didapat dalam karyakarya sastra para pujangga. Namun karya-karya besar itu sering tersimpan rapi diberbagai perpustakaan pribadi maupun umum, kurang diminati oleh kalangan muda karena kalah dengan teknologi modern yang bercitra trendi.
Generasi muda sekarang lebih tertarik memainkan pitur-pitur komputer, gadget, berwhatsApp, instagram atau facebook ria dan sejenisnya daripada membaca, memahami, serta mempraktikan dalam kehidupan nyata berkenaan dengan makna yang terkandung dalam karya-karya sastra besar itu. Untuk tujuan itulah kajian ini dilakukan, dalam upaya memahami lebih dalam berkaitan dengan makna-makna yang terkandung dalam karya sastra itu sebagai pegangan bagi generasi muda dalam menghadapi semakin derasnya pengaruh arus budaya global.

\section{METODE PENELITIAN}

Penelitian ini menggunaan metode kualitatif yang menekankan pada deskripsi mendalam yang bersifat etik, emik, dan holistik dalam perspektif budaya. Lokus penelitiannya dipusatkan di Desa Adat Bresela Kecamatan Payangan Kabupaten Gianyar. Teknik pengumpulan data digunakan teknik pengumpulan data primer dan teknik pengumpulan data skunder. Data yang diperoleh dari sumber primer adalah data yang diperoleh dari informan, foto, dan gambar. Data dari sumber skunder diperoleh melalui penelusuran dokumen terkait seperti arsip dari berbagai instansi, artikel pada media masa, jurnal, dan internet.

Pemilihan informan dilakukan secara purvosive sampling. Dengan teknik purvosive sampling ditentukan tiga macam informan, yaitu informan sebagai anggota perkumpulan sekaa santhi dan informan yang bukan sebagai anggota perkumpulan sekaa santhi, namun mereka secara aktif ikut megeguritan ketika ada kegiatan upacara baik di pura maupun upacara yang diselenggarakan oleh warga masyarakat. Informan berikutnya adalah tokoh-tokoh masyarakat, seperti: Bendesa Adat, Kelihan Adat, Pemangku, dan tukang banten. Di samping dua informan tadi ada informan lain yaitu beberapa warga masyarakat yang diminta kesediaannya untuk memberikan informasi berkenaan dengan geguritan yang disajikan dalam kegiatan upacara yang dimaksud.

Analisis data merupakan proses mengatur urutan data, mengorganisasikan ke dalam suatu pola kategori dan satuan uraian dasar. Analisis data merupakan proses penelaahan seluruh data yang telah tersedia yang diperoleh berdasarkan observasi/pengamatan, wawancara, pencatatan, perekaman, dan studi dokumen yang dilakukan sejak pengumpulan data dimulai. Analisis data dilakukan selama penelitian berlangsung secara deskriptif kualitatif dan interpretatif. Teknik analisis data meliputi: reduksi data, penyajian data, penafsiran data, dan penarikan simpulan.

\section{ANALISIS DAN INTERPRETASI DATA}

Pendidikan secara umum berasal dari bahasa Yunani "paedagogie", yaitu suatu perkataan yang berasal dari akar kata "pais" yang artinya anak, dan "gogie" berarti suatu ilmu. Paedagogie berarti suatu ilmu yang berhubungan dengan 
anak. Dalam perkembangan selanjutnya "paedagogie" juga berarti bimbingan atau pertolongan yang diberikan oleh orang lain atau oleh kelompok orang di dalam membawa perkembangan anak ke tingkat yang lebih tinggi. Pendidikan adalah pembelajaran, pengetahuan, keterampilan, dan kebiasaan sekelompok orang yang diturunkan dari satu generasi ke generasi berikutnya melalui pengajaran, pelatihan atau penelitian.

Danilov (1978) mengatakan paedagogi sebagai proses interaksi terus menerus dan saling berasimilasi antara pengetahuan ilmiah dan pengembangan siswa. Asimilasi yang dimaksud adalah pengetahuan oleh siswa berkaitan dengan antusiasme mereka untuk mengetahui diverifikasi dalam proses kerja yang intensif dan aktif. Perlu diperhatikan adanya penekanan pada aspek pengajaran terus menerus dari proses asimilasi yang merupakan upaya intelektual yang intensif pada diri siswa. Menjaga proses pendidikan dan pengajaran secara keseluruhan dan bermuara pada pembentukan keperibadian siswa adalah fungsi dari paedagogi.

Dalam Undang-Undang Pendidikan No.20 Tahun 2003 pada pasal 1 ayat (1) disebutkan pendidikan adalah usaha sadar dan terencana untuk mewujudkan suasana belajar dan proses pembelajaran agar peserta didik secara aktif mengembangkan potensi dirinya untuk memiliki kekuatan spiritual keagamaan, pengendalian diri, keperibadian, kecerdasan, akhlak mulia, serta keterampilan yang diperlukan dirinya, masyarakat, bangsa, dan negara. Lebih lanjut dijelaskan potensi diri merupakan kemampuan, kekuatan, baik yang belum terwujud maupun yang telah terwujud, yang dimiliki seseorang, tetapi belum sepenuhnya terlihat atau dipergunakan secara maksimal.

Thomas Lickona (1992) mengatakan pendidikan karakter dapat diartikan sebagai upaya untuk membentuk keperibadian seseorang melalui pendidikan yang hasilnya terlihat dalam tindakan nyata seseorang berupa tingkah laku yang baik, jujur, bertanggung jawab, menghormati hak orang lain, kerja keras dan sebagainya. Sementara itu Direktorat Jenderal Manajemen Pendidikan Dasar dan Menengah (2010:2) menyatakan bahwa karakter adalah cara berpikir dan berperilaku yang menjadi ciri khas tiap individu untuk hidup dan bekerjasama, baik dalam lingkup keluarga, masyarakat, bangsa, dan negara. Atas dasar itu maka karakter merupakan nilai-nilai perilaku manusia yang berhubungan dengan Tuhan Yang Maha Esa, diri sendiri, sesama manusia, lingkungan (sekolah/masyarakat), dan kebangsaan yang terwujud dalam pikiran, sikap, perasaan, perkataan, dan perbuatan berdasarkan norma-norma agama, hukum, tata krama, budaya, dan adat istiadat.

Dalam Upedesa (1980/81) disebutkan bahwa tujuan agama Hindu adalah untuk mencapai kedamaian rohani dan kesejahteraan hidup jasmani. Selanjutnya dalam Bhagawad Gita (Puja, 1981:32) disebutkan:
"Moksartham jagadithaya ca iti dharma", yang artinya dharma atau agama itu adalah untuk mencapai moksa (moksartham) dan mencapai kesejahteraan hidup makhluk (jagadhita). Moksa juga disebut "mukti", artinya mencapai kebebasan jiwatman atau kebahagiaan rokhani yang langgeng. "Jagadhita juga disebutkan dengan istilah "Bhukti", yaitu membina "abhyudaya" atau kemakmuran kehidupan masyarakat dan negara".

Berdasarkan tujuan agama Hindu, maka tujuan pendidikan agama Hindu sesungguhnya sama dengan tujuan pendidikan nasional, seperti yang dirumuskan dalam Undang-Undang Pendidikan, yaitu dasarnya adalah membangun manusia Indonesia seutuhnya, artinya membangun secara lahiriah atau wujud nyatanya dan membangun rokhaniahnya yang selaras dengan ajaran dharma dan kaedah-kaedah yang berlaku dalam kehidupan bermasyarakat, berbangsa, dan bernegara. Tujuan pendidikan agama tidak semata-mata hanya menanamkan pengetahuan keagamaan sebanyak-banyaknya, namun yang paling penting yang harus diperhatikan apakah pengetahuan yang telah diberikan mampu dipahami, diresapi, dihayati, dan direfleksikan di dalam kehidupan nyata sehari-hari oleh peserta didik.

Dalam kitab Dharmapada Attakata Sang Budha bersabda: "Meskipun ia hafal banyak seloka kitab suci, tetapi perilakunya tidak sesuai dengan sila, ia dapat diibaratkan sebagai gembala yang bertugas menjaga sapi orang lain. Sebenarnya ia tidak mempunyai bagian untuk mencapai tingkat kesucian. Tetapi meskipun ia hafal sedikit seloka kitab suci, tetapi perilakunya sesuai dengan sila, ia bebas dari semua ikatan nafsu, bersih dari kebencian dan semua ikatan, ia memiliki bagian dari kesucian" (Warta Hindu Dharma, 1983:14).

Berdasarkan uraian di atas dapat dijelaskan bahwa pendidikan menurut agama Hindu pada hakikatnya memiliki dasar konsep yang sama dengan pendidikan nasional. Namun pendidikan dalam perspektif Hindu lebih menekankan pada aspek sikap. Artinya pendidikan dalam perspektif Hindu lebih mengutamakan pembentukan budi pekerti luhur dan jati diri dibandingkan dengan penguasaan terhadap ilmu pengetahuan yang lebih banyak.

Media berasal dari bahasa Latin "medium" yang secara harfiah berarti perantara atau pengantar, yaitu perantara atau pengantar sumber pesan (komunikator) dengan penerima pesan (komunikan). Di dalam proses belajar mengajar, media berarti sarana yang berfungsi menyalurkan pengetahuan dari guru kepada peserta didik. Media pembelajaran yang digunakan dalam kegiatan pembelajaran dapat memengaruhi terhadap efektivitas pembelajaran. Pada awalnya media pembelajaran hanya berfungsi sebagai alat bantu bagi guru untuk mengajar yang digunakan adalah alat bantu visual. Namun belakangan alat bantu visual itu telah dilengkapi alat bantu audio, sehingga lahirlah 
alat bantu audio-visual. Dari sini pengertian media lebih berkembang menjadi alat, metode atau teknik yang digunakan dalam rangka lebih mengefektifkan komunikasi dan interaksi antara guru dengan murid dalam proses pendidikan dan pengajaran di sekolah.

Berdasarkan pengertian itu, maka media dipahami sebagai suatu alat yang digunakan untuk mengefektifkan pesan atau informasi baru kepada murid sebagai penerima pesan, sehingga bagi penerima pesan dapat dengan mudah memahami dan menginterpretasikan pesan tersebut. Atas dasar itu maka peranan media dalam proses pembelajaran sangat penting. Proses belajar itu tidak hanya berlangsung dalam pendidikan formal atau hanya berlangsung di sekolah saja, namun pendidikan itu juga dapat berlangsung di luar sekolah seperti di masyarakat, yang lazim dikenal sebagai pendidikan nonformal, dan di dalam keluarga disebut pendidikan informal.

Ditinjau dari sifat media, megeguritan itu dapat dimasukkan ke dalam media audio yaitu media atau alat bantu yang dipergunakan dengan cara mendengarkan. Oleh karena megeguritan itu adalah aktivitas metembang yang pelaksanaannya tidak terbatas pada kelompok orang saja, melainkan dapat diikuti oleh setiap orang. Atas dasar itulah, megeguritan merupakan salah satu media yang dapat digunakan untuk menanamkan pendidikan karakter pada tri pusat pendidikan, seperti pendidikan formal di sekolah; pendidikan informal di keluarga, dan pendidikan non formal di masyarakat.

Dalam membangun negara dan bangsa yang lebih bermartabat dibutuhkan sumber daya manusia yang berkualitas. Untuk memenuhi sumber daya manusia yang demikian, pendidikan menempati posisi yang sangat strategis. Dalam UU No.20 Tahun 2003 tentang Sistem Pendidikan Nasional, pada pasal 3 disebutkan bahwa pendidikan nasional berfungsi mengembangkan kemampuan dan membentuk watak serta peradaban bangsa, bertujuan untuk berkembangnya potensi peserta didik agar menjadi manusia: yang beriman dan bertaqwa, berakhlak mulia, sehat, berilmu, cakap, kreatif, mandiri, dan menjadi warga negara demokratis serta bertanggung jawab.

Dalam Kamus Besar Bahasa Indonesia (Depdiknas, 2005:506) karakter diartikan sifat-sifat kejiwaan, akhlak atau budi pekerti yang membedakan seseorang dari orang lain. Sementara itu Koesoema (2007) mengatakan pendidikan karakter adalah usaha yang dilakukan secara individu dan sosial dalam menciptakan lingkungan yang kondusif bagi pertumbuhan kebebasan individu itu sendiri. Atas dasar itu maka pendidikan karakter harus mampu memetakan dengan baik hubungan antara pendidikan karakter dengan pembentukan manusia ideal. Yang dikatakan sebagai manusia ideal adalah manusia yang baik secara moral, memiliki peribadi yang kuat dan tangguh secara fisik, mampu mencipta dan mengapresiasi seni, bersahaja, adil, cinta tanah air, bijaksana, beriman teguh pada Tuhan Yang Maha Esa.

Di dalam Kamus Bali Indonesia (1991:254) kata "megeguritan" berasal dari kata "gurit" yang berarti "gubah, karang, sadur", yang mendapatkan akhiran (pengiring - an) menjadi guritan yang berarti gubahan, saduran, karangan. Apabila kata gurit direduplikasi dalam bahasa Indonesia dan mendapat sufik "an", maka akan menjadi kata "geguritan". Geguritan berarti saduran cerita yang berbentuk tembang atau pupuh.

Dalam seni karawitan Bali, geguritan adalah pupuh yang digubah untuk menceritakan suatu kisah cerita rakyat. Kata geguritan yang mendapatkan awalan (pengater - ma), maka menjadilah "megeguritan" yang secara sederhana dapat dirumuskan bahwa "megeguritan" mengandung pengertian memahami isi sebuah cerita lewat melagukan (matembang).

Dalam tulisan yang berjudul "Geguritan Sebuah Bentuk Karya Sastra Bali” (Agastia, 1980) menyebutkan geguritan adalah suatu karya sastra tradisional (klasik) yang mempunyai sistem konvensi sastra tertentu. Geguritan sebagai karya sastra yang konvensio di dalam membacanya tidaklah seperti membaca prosa. Hal ini disebabkan karena geguritan itu dibentuk oleh "pupuh", yang mana pupuh itu diikat oleh beberapa syarat. Syarat-syarat pupuh disebut padalingsa, yaitu banyaknya baris dalam tiap-tiap pada (bait), banyaknya suku kata dalam tiap-tiap carik (baris), dan bunyi akhir pada tiap-tiap baris menyebabkan pupuh itu harus dilagukan.

Dengan adanya keterikatan seperti itu, maka geguritan itu sifatnya masih sederhana, sebab di dalam membaca geguritan dilakukan dengan melagukan. Adapun jumlah tembang yang sudah lumbrah dipakai dalam megeguritan seperti sekar rare, sekar alit, sekar madya, dan sekar agung. Dari masing-masing tembang ini ada bagian-bagian tersendiri, seperti: sekar rare adalah gending-gending macepat, sekar alit adalah pupuh-pupuh, sekar madya adalah kidung-kidung, dan sekar agung adalah kekawin.

Bila ditinjau dari arti katanya, geguritan itu berasal dari bahasa Bali yang artinya "gubah", karang, sadur dalam kata benda karangan, gubahan dan saduran. Selanjutnya kata gurit ini digabungkan dengan vokal maupun konsonan akan menjadi "gurit", dalam bahasa Bali berarti ngurit, artinya mengubah bentuk kata kerja. Apabila kata gurit mendapatkan awalam me, maka akan menjadi kata "magurit", yang menyatakan bahwa sesuatu itu telah digubah. Apabila kata gurit mendapat akhiran an akan menjadi "guritan" artinya gubahan, saduran karangan, dan apabila kata gurit didwipurwayang atau direduplikasikan (Bahasa Indonesia) dan mendapat sufik "an" maka menjadi kata "gaguritan", artinya orang yang melakukan kegiatan matembang. Geguritan itu adalah pupuh yang digubah 
untuk menceritakan, mengisahkan suatu kisah atau cerita rakyat (Mandra, 1982:12).

Atas dasar pengertian di atas, megeguritan dalam tulisan ini dimaksudkan gubahan, saduran cerita-cerita rakyat yang sarat dengan nilai-nilai kearifan, keteladanan, etika dan estetika yang disusun dalam bentuk tembang atau pupuh yang kalau membacanya dilakukan dengan melagukan atau matembang (mageguritan), dalam upaya membangun pendidikan karakter di tengah derasnya arus budaya global.

\section{Tujuan Megeguritan dan Pendidikan Karakter} Tujuan Megeguritan

Agastya (1980:16) mengatakan bahwa geguritan itu merupakan karya sastra tradisional dan klasik yang memiliki sistem konvensi sastra tertentu. Geguritan itu sesungguhnya merupakan salah satu wujud kebudayaan, khususnya kebudayaan yang berbentuk karya sastra Bali. Oleh karena itu sebuah karya sastra itu terwujud adalah didasari oleh cipta, rasa, dan karsa manusia. Karya sastra ini di dalamnya banyak mengandung unsur-unsur pendidikan yang sangat baik bagi manusia khususnya kalangan generasi muda. Sebagai sebuah karya sastra maka harus diketahui oleh setiap manusia semenjak ia dilahirkan sampai akhir hayatnya. Atas dasar itu, maka aktivitas megeguritan yang dilakukan akan dapat melestarikan salah satu wujud kebudayaan.

Dengan adanya aktivitas megeguritan maka dapat dipastikan bahwa karya sastra tradisional tinggalan nenek moyang yang di dalamnya terkandung nilai-nilai kearifan, etika, dan estetika yang amat tinggi ini akan dapat dilestarikan, dan bahkan ke depan akan selalu digali makna-makna yang ada di balik karya satra itu. Oleh karena setiap pupuh yang digunakan untuk melagukan karya sastra itu terimplikasi sebuah watak, karakter atau jati diri sang tokoh. Hal ini tentu sangat positif dijadikan sebagai pola anutan bagi generasi muda dalam rangka memaknai hidup yang selalu berdinamika secara terus-menerus.

Dalam setiap aktivitas megeguritan orang akan memiilih sebuah karya sastra tertentu yang di dalamnya menggambarkan sebuah kejadian atau peristiwa. Untuk melukiskan suatu kejadian atau peristiwa yang ada dalam karya sastra itu dipilihlah pupuh/tembang yang akan menggambarkan peristiwa tersebut. Dalam kaitan ini Agastya (1980:18) menyebutkan sebagai berikut.

a. Pupuh sinom, biasanya dipakai untuk menggugah halhal keindahan, kebahagiaan, kesenangan, keceriaan, kegiatan muda-mudi, pendeknya hal-hal yang menggembirakan.

b. Pupuh durma, dipakai untuk menceritakan hal-hal mengenai kekacauan, peperangan, kemarahan, permusuhan, dan hal-hal seperti itu.

c. Pupuh semarandana, biasanya dipakai untuk meng- gugah diseputar asmara, kasih sayang, tangis, kesedihan, pendeknya hal-hal yang mengharukan.

d. Pupuh pucung, dipakai menceritakan hal-hal yang lucu-lucu, nasehat-nasehat, teka-teki, dan sebagainya.

Berdasarkan uraian di atas, sangat jelas bahwa megeguritan itu bukan hanya dilakukan oleh kalangan tua-tua saja, namun ada geguritan yang cocok untuk kalangan muda-mudi (generasi muda). Sementara di masyarakat sering kali masalah megeguritan diidentikkan dengan orang yang lanjut usia. Artinya aktivitas megeguritan itu hanya cocok dilakukan oleh golongan tua. Namun apabila dilihat dari pupuh yang digunakan, ternyata megeguritan bisa dilakukan oleh generasi muda. Oleh karena itu maka aktivitas megeguritan bukan monopoli dilakukan oleh orang-orang yang sudah tua-tua (lanjut usia), namun megeguritan itu dapat dilakukan oleh semua lapisan masyarakat. Atas dasar itu, maka aktivita megeguritan dapat dijadikan sebagai salah satu media pendidikan karakter. Sebab melalui aktivitas megeguritan banyak hal dapat disampaikan, seperti: pesan-pesan moral, nasehat-nasehat, kasih sayang, keindahan dan sebagainya.

Tujuan Pendidikan Karakter

Sebelum lebih lanjut dibahas tentang tujuan pendidikan karakter, terlebih dahulu akan dipahami tentang pengertian etika. Etika mempunyai kaitan yang sangat erat dengan karakter. Istilah etika berasal dari bahasa Yunani "etos", yang berarti adat, kebiasaan, peraturan perilaku, sama dengan istilah moralitas yang diartikan sebagai perilaku manusia dengan norma-norma yang berlaku di masyarakat.

Secara umum etika dibedakan menjadi dua, yaitu: (1) Etika sebagai kesusilaan, moral, akhlak atau disebut juga sebagai filsafat moral adalah dasar untuk pembentukan sikap ilmiah: (2) Etiket merupakan norma sopan santun yang mengatur tata pergaulan lahiriah. Kedua istilah ini, selanjutnya mengandung makna : (1) acuan berprilaku baik terpuji, misalnya jujur dan berkata yang benar; (2) watak pribadi terpuji, misalnya bersifat patriotik, solider; (3) nilai praktis, misalnya kelogisan, fungsional; dan (4) nilai moral kehidupan manusia, misalnya adil dan teguh pada kebenaran.

Sementara Karakter adalah cara berpikir dan berperilaku yang menjadi ciri khas tiap individu untuk hidup dan bekerjasama, baik dalam lingkup keluarga, masyarakat (sekolah), bangsa dan negara. Oleh karena itu karakter merupakan nilai-nilai perilaku manusia yang berhubungan dengan Tuhan Yang Maha Esa, diri sendiri, sesama manusia, lingkungan (masyarakat), dan kebangsaan yang terwujud dalam pikiran, sikap, perasaan, perkataan, dan perbuatan berdasarkan norma-norma agama, hukum, tata krama, budaya, dan adat istiadat.

Pendidikan nasional bertujuan untuk berkembangnya potensi peserta didik agar menjadi manusia yang beriman 
dan bertakwa kepada Tuhan Yang Maha Esa, berakhlak mulia, sehat, berilmu, cakap, kreatif, mandiri, dan menjadi warga negara yang demokratis serta bertanggung jawab.

Berdasarkan fungsi dan tujuan pendidikan nasional, jelas bahwa pendidikan di setiap jenjang (termasuk pendidikan nonformal di masyarakat), harus diselenggarakan secara sistematis guna mencapai tujuan tersebut. Hal ini berkaitan dengan pembentukan karakter peserta didik dan generasi muda penerus bangsa sehingga mampu bersaing, beretika, bermoral, sopan santun dan berinteraksi dengan masyarakat. Hal ini mengisyaratkan bahwa mutu pendidikan karakter peserta didik/generasi muda cukup mendesak untuk ditingkatkan. Atas dasar itulah maka pendidikan karakter menjadi sangat penting, sebab melalui pendidikan karakter harus mampu memetakan dengan baik hubungan antara pendidikan karakter dengan pembentukan manusia ideal. Karakter dapat menuntun dan mengarahkan perilaku etis manusia yang cenderung bersifat permanen. Karakter menampakkan diri dalam perilaku manusia dalam hubungannya dengan Tuhan, sesama, dan lingkungan.

Untuk membentengi generasi muda agar tidak mudah terseret dalam arus budaya global maka diperlukan pembangunan karakter yang kuat. Membangun karakter yang kuat dapat dilakukan melalui tri pusat pendidikan. Dengan adanya pendidikan karakter yang semula generasi muda dengan begitu saja menerima informasi dan budaya yang masuk tanpa memfilternya tentu dapat dihindarkan sehingga menjadi lebih selektif dalam menerima informasi yang masuk.

Megeguritan sebagai salah satu media pendidikan karakter dapat dijadikan sebagai filter penyaring masuknya berbagai informasi dalam budaya global. Dalam megeguritan banyak hal yang dapat diperoleh, tidak terbatas dalam melagukan, namun yang paling penting bahwa dalam setiap bait-bait geguritan itu tertanam nilai-nilai kearifan yang dapat dijadikan sebagai tatanan sekaligus tuntunan bagi generasi muda dalam menghadapi gempuran budaya global.

\section{Megeguritan, Pendidikan Karakter, Generasi Muda, dan Arus Budaya Global}

Megeguritan sebagai Media Pendidikan Karakter

Dalam perspektif sosiologi, manusia dikatakan sebagai makhluk homo socieus yaitu makhluk berteman. Manusia tidak dapat hidup sendirian, manusia selalu ingin bersama-sama dengan orang lain atau dengan sesamanya. Manusia selalu membutuhkan orang lain dalam menghadapi hidupnya. Manusia hanya dapat hidup dengan sebaik-baiknya, dan bahkan manusia baru akan berarti apabila manusia hidup secara bersama-sama dengan sesamanya dalam wadah masyarakat.

Pernyataan di atas sesungguhnya menegaskan bahwa pada hakikatnya dalam hidupnya manusia selalu memerlukan bantuan antar sesamanya. Artinya manusia tidak dapat dan tidak mungkin dapat hidup seorang diri, namun manusia akan selalu tergantung antar sesamanya. Ketergantungan manusia antar sesamanya disebabkan karena manusia di dalam hidupnya memiliki berbagai macam kebutuhan untuk menopang hidupnya. Untuk memenuhi berbagai kebutuhan itulah manusia menjalin kerjasama satu dengan yang lainnya.

Pada garis besarnya kebutuhan manusia ada dua, yaitu kebutuhan jasmani dan kebutuhan rohani. Kebutuhan jasmani misalnya kebutuhan akan rumah sebagai tempat berteduh, beristirahat, dan bersenda gurau, pakaian, makan, dan pendidikan. Kebutuhan rohani seperti kebutuhan akan kasih sayang dari orang-orang terdekat, harga diri, hiburan, dan sebagainya. Dengan dipenuhinya kebutuhan tersebut, sehingga manusia akan merasa lebih nyaman dan tenang.

Seiring dengan dinamika masyarakat, kebutuhan manusia juga mengalami peningkatan yang luar biasa. Dalam pemenuhan kebutuhan yang beranekaragam itu manusia melakukan usaha-usaha, namun dalam pemenuhan kebutuhan yang semakin kompleks itu terkadang manusia lupa dengan nilai-nilai atau norma-norma yang berlaku dalam hidup bermasyarakat. Agar perjuangan manusia di dalam memenuhi segala kebutuhan hidupnya tidak bertentangan dengan nilai dan norma yang berlaku dalam masyarakat, maka perlu adanya pengendalian diri agar apa yang dikerjakan tidak sampai melanggar aturan-aturan yang ada. Apabila manusia mampu mengendalikan diri untuk menjauhi dan menghindari perilaku yang tidak sesuai dengan nilai dan norma di masyarakat, maka manusia yang demikian dapat dikatakan manusia yang telah memiliki karakter.

Dalam Kitab Sarasmuscaya seloka 41 tentang pelaksanaan dharma dijelaskan sebagai berikut.

"Na tata parasya sandadhyat

Pratikulum yadatmanah

Esa samsepto dharma

Kamadnyat prapartate"

Artinya:

"Adapun yang engkau perhatikan adalah hal yang ditimbulkan oleh perbuatan, perkataan, dan pikiran yang tidak menyenangkan dirimu sendiri, malahan menimbulkan kesusahan yang menyebabkan sakit hati, yang demikian itu janganlah engkau lakukan kepada orang lain, jangan tidak mengukur baju dibawa sendiri perilaku demikian itu singkatnya itulah dharma namanya. Penyimpangan dalam melaksanakan dharma yang demikian hendaknya jangan engkau lakukan” (Puja, 1979 :29).

Apa yang tersurat dalam seloka agama itu sesungguhnya tidak jauh berbeda dengan kearifan-kearifan lokal yang ada pada masyarakat Bali yang disampaikan dengan menggunakan berbagai bahasa simbol. Misalnya bagaimana cara manusia mengendalikan diri dalam hidup bermasyarakat 
yang disampaikan lewat tembang dalam pupuh Pucung sebagai berikut.

"Eda caluh

Nyalanang bikase sigug

Brangti lobangkara

Ento sutsutin di hati

Pang de ngliput

Ngawe saranta di jalan"

Apabila pupuh di atas dicermati secara saksama, di dalamnya mengandung pesan-pesan moral yang begitu dalam bahwa jangan sampai kita berbuat yang kurang baik atau tidak terpuji, seperti momo angkara (loba, serakah atau selalu ingin bagian yang lebih), sebab hal itu akan dapat mengakibatkan manusia tersesat dalam hidup ini. Seandainya pesan-pesan seperti itu dapat diresapi terutama oleh anak-anak remaja sebagai penerus kehidupan bermasyarakat, maka keharmonisan dan kedamaian akan selalu terpelihara dalam hidup bermasyarakat.

Berpijak pada dua kutipan pupuh di atas maka sangat jelas tersirat sebuah makna bahwa suatu etika atau karakter dapat menyangkal yang ditimbulkan oleh pikiran, perkataan, dan perbuatan (Tri Kaya Parisuda). Atas dasar itu, maka dapat dikatakan bahwa megeguritan dapat dijadikan sebagai salah satu media dalam menanamkan pendidikan karakter di kalangan generasi muda. Merupakan suatu fakta bahwa di dalam syair-syair geguritan itu banyak tersembunyi nilai-nilai karakter yang sangat bermanfaat baik bagi pembaca syair-syair itu maupun bagi mereka yang mendengarkannya.

Atas dasar itu maka dapat dipastikan bahwa kegiatan megeguritan berdampak positif terhadap keperibadian seseorang. Sebab melalui kegiatan megeguritan seseorang dapat mengekspresikan seninya dengan cara melagukan (guru lagu), di samping itu di dalam syair-syair yang sedang dilagukan di dalamnya banyak terkandung pedoman/ petunjuk tentang kebenaran, sehingga mereka dapat membedakan mana perbuatan yang dibenarkan dan mana perbuatan yang harus dihindarkan dan bila perlu jangan dilakukan. Misalnya petunjuk tentang perbuatan baik dapat ditunjukkan dalam sebuah pupuh durma seperti berikut:

"Sang nyidayang ngeret indriya lan manah

Panjang yusa to kapanggih

Langgeng jroning yoga

Luput saking papa klesa

Nyama braya

Sami asih tulus bhakti"

Dalam pupuh durma di atas terimplikasi sebuah makna bahwa setiap orang atau siapa saja yang mempunyai kemampuan dan berhasil mengendalikan indria (pengendalian diri), dapat dipastikan orang itu berusia panjang, tidak akan kekurangan apa-apa termasuk teman semuanya akan bersikap baik kepadanya. Hidup mereka tenang, nyaman, dan tidak memiliki beban karena semua orang dapat me- nerima mereka sebagai teman. Mereka tidak memilih dan membeda-bedakan teman, semua teman mereka terima apa adanya.

Aktivitas megeguritan merupakan salah satu cara untuk menuntun sikap dan karakter seseorang. Sebab di dalam syair-syair geguritan banyak contoh-contoh tentang pikiran, perkataan, dan perbuatan yang pantas untuk dilakukan dan yang kurang pantas untuk dilakukan. Contoh dalam syair geguritan dengan pupuh pangkur berikut ini.

"Manut bawos sang pradnyan

Ne kacatur

Patut baktinin tindihin

Tan lian sang catur guru

Guru rupaka pertama

Ne ping rua

Guru pengajian bagus

Ne ping telu kesinahang

Guru wisesa utami",

Geguritan di atas mengandung makna bahwa di dalam kehidupan ini siapapun tidak dapat lepas dari sang pradnyan (orang pintar). Sang pradnyan menyebutkan bahwa dalam hidup ini ada empat (4) guru (catur guru) yang harus dan wajib dihormati. Menghormati guru bukan karena usianya atau karena jabatannya, namun menghormati guru mengandung makna mengikuti semua petunjuk yang diberikan. Namun dalam perkembangan dan kemajuan teknologi dewasa ini, tidak dapat dipungkiri orang yang lebih senior sering berguru kepada mereka yang lebih yunior yang lazim dikenal sebagai generasi milenial.

Disebut sebagai guru, karena mereka yang patut dicontoh atau diteladani, mulai dari cara berpikirnya, perkataannya, dan perbuatannya. Dalam arti mereka yang memiliki kharisma dan wibawa sehingga pantas untuk ditiru dan diteladani. Disebut sebagai guru, karena rata-rata kemampuan yang dimiliki sangat dibutuhkan oleh yang lain sebagai pedoman berpikir, berkata, dan berperilaku. Dalam pemahaman yang sederhana guru adalah mereka yang memberikan ilmu pengetahuan kepada yang lain. Dalam pandangan masyarakat, guru adalah orang yang melaksanakan pendidikan di tempat-tempat tertentu (sekolah, di rumah, masyarakat).

Pada era globalisasi, terutama mencermati perkembngan IT (informasi Teknologi) atau yang lazim dikenal era-digital yang demikian canggih, nampaknya konsep catur guru mestinya sudah dikembangkan menjadi panca guru, dengan menampilkan konsep guru suputra. Dengan kecanggihan teknologi terkadang banyak orang tua yang belum siap (gatek), sehingga mesti belajar kepada anak-anak muda yang lazim dikenal dengan anak-anak milineal, seperti apa yang pernah diungkapkan sosiolog Karl Mannheim dalam sebuah tulisan yang berjudul The "Problem of Generations" tahun 1923. Melalui tulisan itulah dikenal konsep 
generasi baby boomer, generasi X, generasi Y (milenial), generasi $\mathrm{Z}$, dan generasi alpha.

Generasi Muda dalam Pusaran Arus Budaya Global Arus globalisasi yang begitu cepat masuk ke dalam masyarakat membawa pengaruh yang begitu kuat, terutama bagi generasi muda. Pengaruh globalisasi itu dapat membuat generasi muda kehilangan keperibadian dan jati diri mereka sebagai bagian dari masyarakat Indonesia. Kehilangan keperibadian dan jati diri, ditunjukkan melalui gejala-gejala yang timbul dalam kehidupan sehari-hari. Salah satu misalnya cara berpakaian serba minim yang ditampilkan generasi muda lebih cenderung mengikuti penampilan budaya barat.

Pemuda kerapkalai diidentikkan dengan golongan yang memiliki sifat progresif, inovatif, memiliki sensivitas sosial-politik yang sangat peka terhadap perubahan, dan berbagai predikat lainnya. Sejarah negeri inipun mencatat betapa besar peranan pemuda sebagai perintis, penggalang, penggerak, dan pendobrak menuju cita-cita kemerdekaan. Selanjutnya pemuda juga telah menunjukkan dirinya sebagai penegak bahkan mampu sebagai pelopor untuk memformat ulang kehidupan kebangsaan sesuai cita-cita proklamasi yang harus disesuaikan dengan perkembangan dan tuntutan jaman.

Globalisasi telah membentuk peradaban jaman dengan menyertakan gaya hidup praktis dan pragmatis. Bahkan globalisasi oleh sebagian generasi muda telah dijadikan sebagai "isme" baru dengan menderivat paham-paham kepraktisan hidup seperti materialisme, hedonisme hingga sifat konsumtif. Kondisi inilah yang terkadang memosisikan generasi muda ke suatu ruang yang memasung mereka ke dalam kenyamanan peradaban kapitalisme.

Dampak globalisasi di kalangan generasi muda di Bali telah menimbulkan situasi kegelisahan, sehingga masyarakat Bali merasa perlu mengadakan reorientasi kembali terhadap kebudayaan Bali itu sendiri untuk menanggulangi atas kekhawatiran itu. Masyarakat Bali sangat meyakini Bali memiliki keunggulan lokal (local genius), Bali memiliki kearifan lokal (local wisdom) yang sekiranya dapat dijadikan sebagai rujukan bagi generasi muda dalam menghadapi pengaruh negatif arus budaya global (Brata, 2016).

Budaya asing yang masuk terbungkus rapi globalisasi mereka konsumsi dalam arti diterima secara langsung, mereka lupa sebagai orang Bali memiliki karakter, adat budaya sebagai bangsa ketimuran. Budaya asing yang mereka saksikan lewat media sosial (TV, internet) atau yang mereka dapatkan melalui interaksi secara langsung dengan orang lain sering kali mereka tidak olah terlebih dahulu. Apa yang mereka lihat dan rasakan langsung mereka adopsi tanpa pernah berpikir apakah hal itu cocok bagi diri dan lingkungannya sebagai orang Bali.
Dalam upaya mengantisipasi dampak negatif arus budaya global di kalangan generasi muda maka dibentuklah sekaa-sekaa santhi. Dalam wadah sekaa-sekaa santhi/ pesanthian ini dilibatkan anak-anak muda/generasi muda. Pada awalnya anak-anak muda sangat enggan ikut kelompok pesanthian. Mereka punya alasan bahwa sekaa santhi itu identik dengan orang-orang sepuh (tua). Dengan memberi pemahaman yang secara terus menerus dilakukan oleh tokoh-tokoh masyarakat, terutama tokoh-tokoh sekaa santhi akhirnya membuahkan hasil, dengan ditunjukkan beberapa anak-anak muda desa mulai ikut dalam kegiatan megeguritan. Pada awalnya mereka ragu-ragu dan bahkan canggung, namun lama kelamaan akhirnya menjadi terbiasa tampil pada saat-saat upacara piodalan di pura atau di rumah warga apabila ada upacara-upacara tertentu, bahkan dewasa ini ada lomba megeguritan.

Para generasi muda sadar bahwa megeguritan itu ternyata penting bagi kehidupan sosial budaya masyarakat Hindu Bali. Sebab megeguritan itu memiliki beberapa fungsi, seperti: (1) fungsi ketuhanan, artinya lewat megeguritan mereka tahu bermacam-macam sebutan dari Tuhan dan bagaimana cara mengagungkan Tuhan; (2) fungsi pendidikan moral (etika), artinya mereka memahami bahwa dalam teks geguritan terdapat tokoh-tokoh yang mengajarkan etika, agama yang patut dicontoh dan diteladanin; (3) fungsi upacara (ritual), artinya mereka memahami bahwa kidung, nyanyian (sebagai bagian dari panca gita) yang wajib ada untuk mengiringi sebuah yadnya; (4) fungsi pendidikan, artinya mereka memahami bahwa dalam megeguritan itu ada metode pendidikan seperti cara membacanya, bahasa, dan artinya serta makna yang terkandung di dalamnya; (5) fungsi estetika, artinya mereka dapat mengetahui kemampuan, suasana hati atau perasaan pengarang ketika menciptakan syair dalam geguritan itu. Berdasarkan fungsi-fungsi di atas, maka sangat diyakini aktivitas megeguritan dapat dijadikan sebagai salah satu media pendidikan karakter di kalangan generasi muda dalam upaya mengantisipasi dampak negatif yang ditimbulkan oleh arus budaya global. Nilai-nilai yang terkandung di dalam karya sastra yang adiluhung tersebut terkandung nilai-nilai luhur bangsa sebagai kearifan lokal yang dapat dijadikan sebagai mekanisme kontrol atau sebagai pedoman dalam berpikir, berkata, bertingkah laku, dan bersikap bagi masyarakat terutama bagi generasi muda, agar tumbuh dan berkembang sebagai sosok generasi emas yang tangguh, unggul, mampu bersaing, dan yang paling penting tidak tercerabut dari akar budaya bangsanya.

\section{SIMPULAN}

Berdasarkan uraian di atas beberapa hal dapat disimpulkan sebagai berikut; Arus budaya global yang hadir di tengah-tengah masyarakat membawa pengaruh besar. Pengaruh budaya global itu dapat membuat generasi muda 
kehilangan keperibadian atau jati diri yang tampak nyata dalam kehidupan sehari-hari. Globalisasi telah membentuk peradaban jaman dengan menyertakan gaya hidup praktis dan pragmatis. Bahkan globalisasi oleh sebagian generasi muda telah dijadikan sebagai "isme" baru dengan menderivat paham-paham kepraktisan hidup seperti materialisme, hedonisme hingga sifat konsumtif. Kondisi inilah yang terkadang memosisikan generasi muda ke suatu ruang yang memasung mereka ke dalam kenyamanan peradaban kapitalisme.

Membentengi generasi muda agar tidak mudah terseret dalam arus budaya global maka diperlukan pembangunan karakter yang kuat. Membangun karakter yang kuat dapat dilakukan melalui tri pusat pendidikan. Dengan adanya pendidikan karakter yang semula generasi muda dengan begitu saja menerima informasi dan budaya yang masuk tanpa memfilternya tentu dapat dihindarkan sehingga menjadi lebih selektif dalam menerima informasi yang masuk.

Megeguritan sebagai salah satu media pendidikan karakter dapat dijadikan sebagai filter penyaring masuknya berbagai informasi dalam budaya global. Dalam Megeguritan banyak hal yang dapat diperoleh, tidak terbatas dalam melagukan, namun yang paling penting bahwa dalam setiap bait-bait geguritan itu tertanam nilai-nilai kearifan yang dapat dijadikan sebagai tuntunan bagi generasi muda dalam menghadapi gempuran budaya global.

\section{DAFTAR RUJUKAN}

Agastia, Ida Bagus Gede. (1980), Geguritan sebagai Bentuk Karya Sastra Bali. Panitia Pelaksana Pesta Kesenian Bali.

Brata, Ida Bagus. (2016), Kearifan Budaya Lokal Perekat Identitas Bangsa. Jurnal Bakti Saraswati:Denpasar

Kemenuh, Ida Pedanda Putra. (1983), Geguritan Dharma Prawerti. Seksi Bimas Hindu dan Budha Departemen Agama Kabupaten Buleleng.

Ki Hajar Dewantara. (2004), Pendidikan. Majelis Luhur Persatuan Taman Siswa: Yogyakarta

Koentjaraningrat. (2008), Kebudayaan Mentalitas dan Pembangunan. PT Gramedia Pustaka Utama: Jakarta.

Koesoema, Doni A. (2007), Pendidikan Karakter Strategi Mendidik Anak di Zaman Global. Grasindo: Jakarta.

Konta, Anak Agung Alit dan Putra. Tt. Bandana Wandana Yuda. Penerbit Proyek Penelitian Buku dan Sastra Indonesia.
Lickona. Thomas. (1992), Educating for Character. How Our School Can Teach Respect and Respossibility. A Bantam Book: New York.

Mantra, I B. (1996), Bali Masalah Sosial dan Modernisasi. PT Upada Sastra: Denpasar.

Pudja, Gede dan Sudharta. Tt. Menawa Dharma Sastra. Proyek Pengadaan Penelitian Kitab Suci Hindu dan Budha Departemen Agama RI.

Pudja, Gede. Tt. Sarassmuscaya. Proyek Pengadaan Buku Kitab Suci Hindu Departemen Agama RI.

Tilaar, H.A.R. (2007), Mengindonesia Etnisitas dan Identitas Bangsa Indonesia Tinjauan dari Perspektif Ilmu Pendidikan. PT.Rineka Cipta: Jakarta.

Tilaar, H.A.R. 2002. Pendidikan, Kebudayaan dan Masyarakat Madani Indonesia. PT. Remaja Rosdakarya: Bandung.

\section{Daftar Nara Sumber/Informan}

Astawa, I Wayan Nopan. (22 tahun), pemangku, wawancara Sabtu, 28-9-2017 di rumahnya Banjar Bresela Payangan Gianyar.

Merta, Ida Ayu Putu. (57 tahun), Tukang Banten, wawancara Minggu, 8 -9-2017 di rumahnya di Banjar Triwangsa Bresela Payangan Gianyar.

Mika, I Made. (49 tahun), Kelihan Adat/wirausaha, wawancara Minggu, 15-9-2017 di rumahnya Banjar Gadungan Payangan Gianyar.

Nirbhanawasa, Ida Bagus Made. (53 tahun), PNS, wawancara Sabtu, 14-9-2017 di rumahnya Banjar Triwangsa Bresela Payangan Gianyar.

Suryana, I Made. (29 tahun), wirausaha, wawancara Minggu, 22-9-2017 di rumahnya Banjar Gadungan Payangan Gianyar. 